\title{
Devolver ao remetente ${ }^{1}$
}

\author{
Tiago Bartolomeu Costa
}
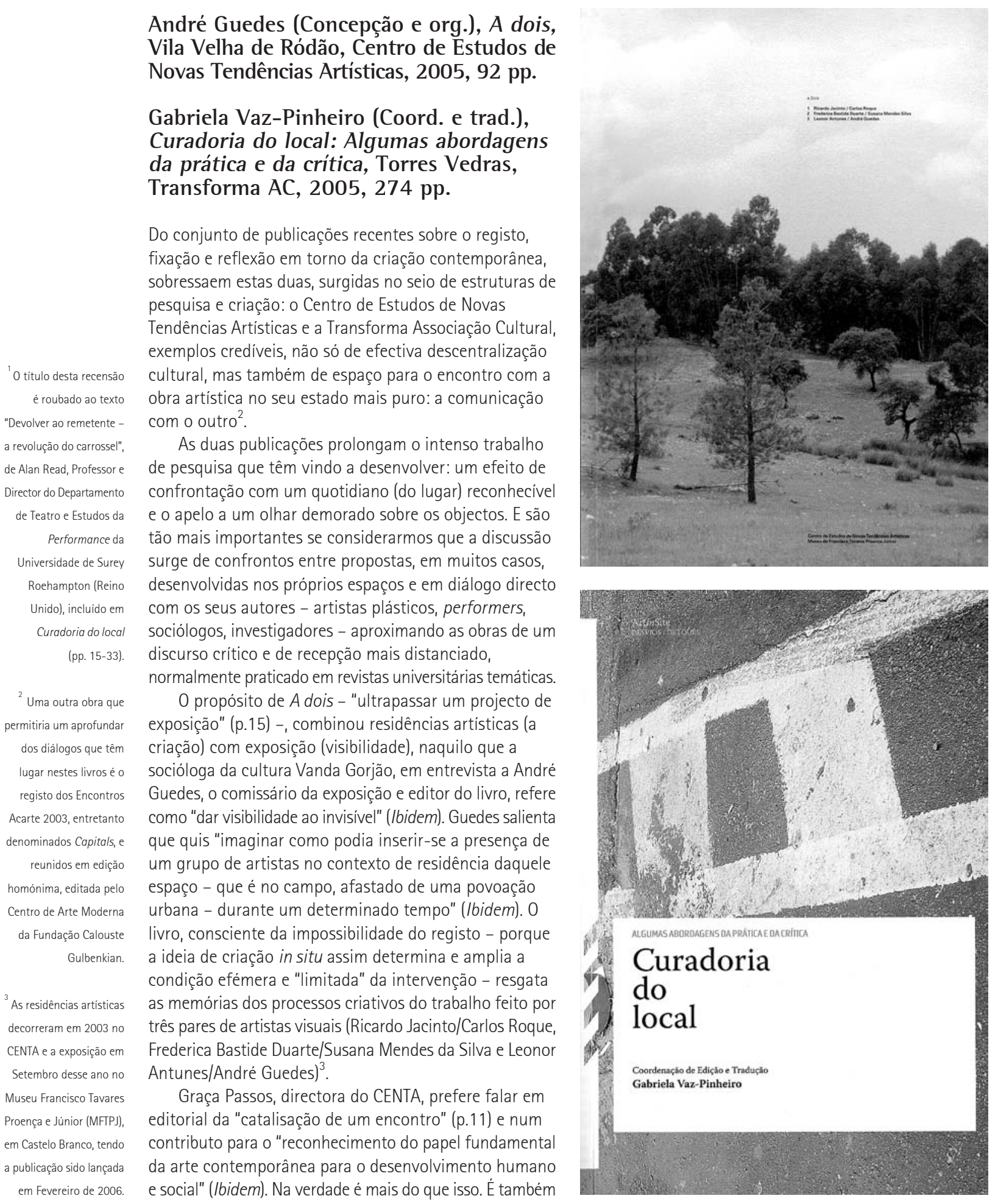
uma viagem pelo percurso pessoal e criativo de cada um dos artistas, pelo modo como se envolveram com o espaço e a proposta, e como, auxiliados pela distância, são capazes de reflectir sobre o que fizeram. 0 livro, em edição bilingue, contém diálogos com criadores - fornecendo novas pistas para o entendimento de uma obra em aberto -, uma ampla cobertura fotográfica das obras, tanto em processo como em exposição, a contextualização do projecto e ainda o trabalho desenvolvido pelo Serviço Educativo do CENTA e do MFTPJ.

Falamos aqui de uma vontade de marcar o tempo e o lugar. 0 projecto desenvolvido pelos artistas amplifica o espaço do CENTA - uma imensa herdade encravada no vale de Vila Velha de Ródão que tem sido palco para as mais variadas experiências estéticas no domínio das artes contemporâneas, nomeadamente as visuais e performativas - enquanto tela viva onde se conjuga o vídeo, a instalação cenográfica, a escultura, a intervenção performativa e a noção de espaços aos quais nada se pode acrescentar. Esta ideia transforma o exercício de descoberta (a criação e a leitura do livro) numa pertinente reflexão sobre a condição de criação site-specific.

Estão na ordem do dia questões dependentes de uma nova forma de pensar as artes performativas. A convocação de outras ciências para o estudo da arte efémera, e a vontade de entrecruzar disciplinas, têm feito accionar mecanismos de deslocação do discurso da teoria e da crítica teatral (e o termo "teatro" existe aqui por defeito, deveria ler-se "representação") para relações com a sociologia e a antropologia. Se é relevante que assim seja - porque se assume que a dança ou o teatro não são só dança e teatro, mas disciplinas de estudo da sociedade contemporânea -, podemos incorrer na criação de termos, não só impraticáveis, como história e culturalmente inadaptados, deslocados e reflexo de ausência de memória, como seja a "transdisciplinaridade" e o "hibridismo".

Nesta ordem de ideias, Curadoria do local é uma proposta de discussão sobre o que está em causa quando falamos da relação entre espaço e criação. 0 livro é, também ele, fruto de encontros, debruçando-se "sobre os mais recentes desenvolvimentos ao nivel das práticas artísticas contemporâneas que procuram estabelecer novas formas de relacionamento com as sociedades actuais, bem como sobre o pensamento que questiona a produção artística nesses contextos" (p.12). Procurando ser mais abrangente no alcance das intervenções, reúne as actas do Encontro internacional sobre a importância do local no pensamento e na arte contemporânea, que decorreu em Torres Vedras a 24 e 25 de Setembro de 2004, apresentando as participações de oito intervenientes, divididos entre a antropologia, as artes plásticas, o teatro, o cinema e a sociologia. As intervenções são acompanhadas de documentação visual que contextualiza o discurso.

Curadoria do local, que inaugura a colecção Desvios, constitui-se então como oportunidade para pensar no modo como certas retóricas podem limitar o alcance dos objectos propostos. Isto porque todo este discurso sobre o contemporâneo e a sua recepção é, ele mesmo, efémero. A terminologia e o seu significado, porque usados com frequência ou limitados no seu raio de acção - anexos ao tempo e circunstâncias em que surgiram -, tendem, na evolução dos objectos que analisam, a tornar-se quase impeditivos de uma verdadeira apreciação. Parece ser essa a posição de Gabriela Vaz-Pinheiro, artista plástica e teórica, especialista em questões relacionadas com o espaço, em relação ao uso da expressão site-specificity. No ensaio (pp. 67-85) que dá título ao livro, apesar de reconhecer que o termo foi bastante útil nos anos 60 para a definição de objectos artísticos pensados a partir/em relação ao espaço, salienta, no entanto, que o mesmo carece hoje de nova actualização. Tanto assim é que, segundo a autora, é importante conceber permanentes variações à triade "obra de arte-observador-local". E justifica: "as funções da obra de arte têm sido constantemente reinventadas ao longo dos séculos. De religiosas a celebratórias, de produto comercial a objecto de encantamento ou contemplação, é talvez pela escolha de funções (necessária e frequentemente múltiplas) que tanto o sistema da arte como os artistas decidem atribuir à obra de arte, que novos modos de produção se desenvolvem. As diferenças de função determinam, consequentemente, diferenças de finalidade e resultado" (p. 72).

Reside aqui a importância fundamental destes dois objectos em forma de livro. Se por um lado abrem pistas para a fruição dos objectos artísticos, por outro criam novas relações entre artista e espectador. Importa pensar se a criação de obras de arte está ou não dependente da sua exibição/confrontação pública. André Guedes, em A dois, diz que "a residência vem dar visibilidade ao que permanece lateral" (p.15), enquanto Gabriela Vaz-Pinheiro afirma (Curadoria do local, p.117) a necessidade de separar o que cabe ao artista e o que cabe ao avaliador, posição contrariada por Patricia Brown": "Eu acho que o papel dos artistas é questionar a lógica de tudo isto" (Ibidem).

A procura de uma plataforma de entendimento, ambicionando através dela a constituição de um discurso sobre o fazer artístico, tem que ser pensada quer a partir do efeito que um ambiente provoca num criador (e o leva a querer intervir), quer nesse mesmo ambiente transformado após a inserção da obra e apresentação ao espectador. 0 mérito destes dois livros reside, por isso mesmo, na oportunidade de se constituirem enquanto ponte de diálogo entre o fazer, o pensar e o observar.
${ }^{4}$ Directora executiva da Central London Partnership, que neste livro apresenta um estudo sobre a intervenção pública de artistas em zonas da cidade de Londres ("Criando lugares: 0 papel da arte no desenvolvimento da cidade", pp.34-59). 